\title{
"Book Nerds" United: The Reading Lives of Diverse Adolescents at the Public Library
}

Sarah A. Evans, Texas Woman's University, USA

\begin{abstract}
This research asks the question: How does a public library contribute to the literate lives of a diverse community of adolescents? To explore this question, this article presents portraits of three young women, for whom a public library provided transformative opportunities. These portraits come from a larger ethnographic case study that examined a public library's role in sparking and sustaining adolescent learning. Over 18 months, the author observed library activities involving youth, interviewed library staff and adolescent patrons, and led teen volunteers in a participatory research project. Data were analyzed in a constant comparative method within a sociocultural-historical framework. Through attention to the girls' activities within the public library, two contributing elements-1) a democratic space created by library practices, and 2), the diversity in discourse facilitated by the teen librarian- expanded the participants' literacy practices and perspectives on reading. This article informs our understanding of diversity in adolescent literacy and highlights the practices that libraries and communities can use to foster the next generation of readers.
\end{abstract}

Keywords: adolescents; immigrants; libraries; literacy; reading

Publication Type: research article

\section{Introduction}

ibraries are more than books. To be counted as a public library in the United States, an organization must offer not only materials (including books and non-book items), but also offer staff, services, and facilities that are, at least in part, publicly funded (Institute of Museum and Library Services [IMLS], 2015). Congruently, librarians have frequently reiterated a "we are more than books" message, to evolve a citizenry which may tend to view libraries as outmoded book warehouses. As recently as July 2018, Forbes magazine published an economic professor's argument that, for the benefit of American taxpayers, all U.S. public libraries should be replaced with brick-and-mortar Amazon bookstores. In response to the posting of this article, a legion of librarians, library patrons, and even publishers swarmed Twitter with stories and statistics, effectively countering each premise in the article and criticizing the author's privileged viewpoint. Within two days, Forbes retracted the article, while news outlets marveled at the fierce, rapid response the piece had generated (Lyons, 2018).

In similar efforts to outmaneuver critics who devalue the public library's place in today's society, some library advocates use the phrase, "the library is not about books." While I appreciate their zeal in highlighting public libraries' multiple community-oriented frameworks, this shoving aside of the long-form texts, print or digital, that we call books, is a step too far. Historically, Americans report valuing, even "loving," the public library 1) for making useful information

The International Journal of Information, Diversity, \& Inclusion, 3(2), 2019

ISSN 2574-3430, jps. library.utoronto.ca/index.php/ijidi/index

DOI: $10.33137 /$ ijidi.v3i2.32589 
accessible, particularly to disenfranchised populations, 2) for providing community public spaces, and, most notably to this author, 3) for the "transformative potential" of people engaging with a variety of texts (Wiegand, 2015). As a former public librarian and now researcher, I can confirm that the professional duties of a public librarian still include the reading and sharing of books. In fact, I argue that it is librarians' love of books, combined with their professional practices, that creates one of the most valuable contributions to society, especially when they are working with diverse youth.

Within schools, teachers need to focus pupils' interactions with texts, first on learning to read, and then on reading in order to learn a specific set of skills and knowledge. Outside of school, public librarians working with children and teenagers, freed from instructional requirements, can focus on the joy of reading and on reading to follow their own interests. Additionally, the fact that the public library is open access- both intellectually and physically- creates the potential for more diverse interactions between people from across a range of age, ability, class, ethnicity, and other identity categories. Most public libraries designate a "teen services" librarian to focus on the needs of youth. Since the late 19th century, such librarians have worked to ensure that the diverse adolescents in their communities have access to useful information, a communal space within the library, and opportunities for transformation through engagement with books (Burek Pierce, 2016; Critcher Lyons, 2016; Edwards, 1974; Shera, 1949).

Despite the long history, little empirical research exists on the relationship between public libraries and adolescent readers. Even less is known about the reading lives of the diverse adolescents who increasingly form the majority in many schools and communities across the country. More insight into these phenomena would strengthen responses to library critics as well as increase our field's understanding of adolescent literacy. This article asks the question- how does a public library contribute to the literate lives of a diverse community of adolescents? In answer, I offer portraits of three readers, a diverse set of young women for whom a public library did provide transformative opportunities. These portraits come from a larger ethnographic case study that examined a public library's role in sparking and sustaining adolescent learning. Through attention to these girls' activities within the public library, I identified two contributing elements- a democratic space created by library practices and the diversity in discourse facilitated by the teen librarian. While this article features only a few participants at a single library, these identified elements relate to long-standing library values in practice across the nation, and perhaps, the world. Therefore, these empirical observations can offer insight into public libraries generally, as well as direction for improving library services to diverse youth everywhere.

\section{Literature Review}

\section{Public Library Values}

The free public libraries we know today arose in parallel with the establishment of public schools in the 19th century. The library was seen as the schools' counterpart in the pursuit of universal literacy: "the people's university" that would educate those not captured by the emerging school systems (Shera, 1949). Immigrants and laborers were particularly seen to be in need of the education that was available to them within books and other materials, and the public library was the way for them to access this education. Libraries, likes schools, were responsible for the development of capable citizens who could actively participate in political life and help ensure good government of the nation (Critcher Lyons, 2016). This idea is what

The International Journal of Information, Diversity, \& Inclusion, 3(2), 2019

ISSN 2574-3430, jps.library.utoronto.ca/index.php/ijidi/index

DOI: $10.33137 /$ ijidi.v3i2.32589 
scholars call "the library faith," essentially the belief that libraries contribute to the public good, through "a variety of outcomes, causes, and social aims" depending on who may be asked about the purpose of the library, when, and what the current civic situation in the nation or local region may be (Barniskis, 2017).

Over the course of the 20th century, librarians developed moral codes to guide their provision of library services, found in documents such as the Library Bill of Rights, originally adopted in 1939 (American Library Association [ALA], 1996), and the Freedom to Read Statement, originally adopted in 1953 (ALA \& Association of American Publishers, 2004). In 2004, the ALA culled from their policy statements eleven "Core Values of Librarianship" that "define, inform, and guide our professional practice" (ALA, 2004). Table 1 lists these values and their definitions, as they appear in the ALA Policy Manual.

Table 1. Core Values of Librarianship

\begin{tabular}{ll}
\hline Value & Definition \\
\hline Access & All information resources that are provided directly or \\
indirectly by the library, regardless of technology, format, or \\
methods of delivery, should be readily, equally, and \\
equitably accessible to all library users. \\
Protecting user privacy and confidentiality is necessary for \\
intellectual freedom and fundamental to the ethics and \\
practice of librarianship. \\
A democracy presupposes an informed citizenry. The First \\
Amendment mandates the right of all persons to free \\
expression, and the corollary right to receive the \\
constitutionally protected expression of others. The publicly \\
supported library provides free and equal access to \\
information for all people of the community the library \\
serves. \\
We value our nation's diversity and strive to reflect that \\
diversity by providing a full spectrum of resources and \\
services to the communities we serve. \\
ALA promotes the creation, maintenance, and enhancement \\
of a learning society, encouraging its members to work with \\
educators, government officials, and organizations in \\
coalitions to initiate and support comprehensive efforts to \\
ensure that school, public, academic, and special libraries in \\
every community cooperate to provide lifelong learning \\
services to all. \\
Wearning
\end{tabular}

The International Journal of Information, Diversity, \& Inclusion, 3(2), 2019

ISSN 2574-3430, jps.library.utoronto.ca/index.php/ijidi/index

DOI: $10.33137 /$ ijidi.v3i2.32589 


\begin{tabular}{ll}
\hline Value & Definition \\
\hline The Public Good & ALA reaffirms the following fundamental values of libraries \\
in the context of discussing outsourcing and privatization of & library services. These values include that libraries are an \\
essential public good and are fundamental institutions in \\
democratic societies.
\end{tabular}

Preservation

The Association supports the preservation of information published in all media and formats. The association affirms that the preservation of information resources is central to libraries and librarianship.

Professionalism

The American Library Association supports the provision of library services by professionally qualified personnel who have been educated in graduate programs within institutions of higher education. It is of vital importance that there be professional education available to meet the social needs and goals of library services.

Service

We provide the highest level of service to all library users ...We strive for excellence in the profession by maintaining and enhancing our own knowledge and skills, by encouraging the professional development of co-workers, and by fostering the aspirations of potential members of the profession.

Social Responsibility
ALA recognizes its broad social responsibilities. The broad social responsibilities of the American Library Association are defined in terms of the contribution that librarianship can make in ameliorating or solving the critical problems of society; support for efforts to help inform and educate the people of the United States on these problems and to encourage them to examine the many views on and the facts regarding each problem; and the willingness of ALA to take a position on current critical issues with the relationship to libraries and library service set forth in the position statement.

Note. Text reprinted from "The Core Values of Librarianship," by ALA (2004). Retrieved from http://www.ala.org/advocacy/intfreedom/corevalues.

While some scholars criticize these documents and their values as "unrealistic" for the daily practice of librarianship, Shannon Oltmann (2016) found that public library directors' own language will echo the guidance offered in these documents. Shannon Crawford Barniskis (2016a, 2016b) found in two separate studies that access remains a top value for public library mission statements as well as the values related to education and lifelong learning. The public library continues to interpret and implement these moral codes in relationship to their specific communities.

The International Journal of Information, Diversity, \& Inclusion, 3(2), 2019

ISSN 2574-3430, jps.library.utoronto.ca/index.php/ijidi/index

DOI: $10.33137 /$ ijidi.v3i2.32589 


\section{Library Services for Teens}

For librarians who work with youth, their version of "library faith" has long been grounded in the power of reading. Betsy Hearne and Christine Jenkins (1999) analyzed the writings of the earliest youth services librarians, "the foremothers," and found an emphasis on values beyond the utilitarian purposes of gaining knowledge for school or for work. Youth librarians have, and still do consider the "magic" of reading to be in its capacity for transportation, emotional engagement, and the formation of identity. Youth librarians' faith in reading and the outcomes they hope for are more holistic than those of youth workers in most other contexts. Continuing through to today, publishers busily court librarians at every meeting of the ALA because librarians liaise between what scholars have called "book people" and "child people" (Wolf, Coats, Enciso, \& Jenkins, 2011). Librarians connect the "book people" (authors, publishers, and critics) to the "child people" (parents and teachers), as well as to the children and adolescents themselves. While authors and readers can now connect directly through internet technologies, librarians are still seen as a trusted link by both sides. Even as the format of stories and our means of accessing them has expanded to include such technologies as video games and mobile phones, librarians still believe in this "magic" of reading and in the value of their own role in connecting youth to such experiences (Agosto, 2016).

The best teen services librarians know the importance not only of connecting teens to books, but also of connecting to the teens themselves. Rachel Randall (2013) set out to discover how teens select fiction to read in their local public library. The most prominent theme that emerged from the youth focus groups she studied was the value they placed on personal relationships with library staff. Teens repeatedly emphasized that "it is the little details that count like remembering names, where they go to school, what courses they take, what books they took out the last time" which influenced not only their decision to pick up a book, but also to continue to read (Randall, 2013, p. 21). In documents produced by the Young Adult Library Services Association, the professional organization for library staff that work with teens, librarians are encouraged to develop real relationships with youth because young adults need connection with "compassionate," "non-supervisory" adults (Takahashi, 2015). These relationships in turn support the work of the librarian.

The role of library book discussions, a hallmark of library services for teenagers, was explored by both Donna Alvermann and her coauthors and by Jennifer Wolf. Alvermann and colleagues (1999) set out to study how adolescent after-school "talk" in public library Read and Talk Clubs was shaped by institutional and societal pressures. Teenagers participated because it served as a major social outlet, offering a safe place to authentically talk about what they read and to enjoy their identity as avid readers. Additionally, an analysis of the discursive practices of club members revealed a growing awareness of how literacy, gender, adolescence and adulthood position individuals differently. Despite this growing awareness, however, these readers still chose to use gender and social class status as tools to shape their positions relative to other group members.

To understand how adolescents engaged with contemporary young adult literature, Jennifer Wolf (2006) spent just under two years observing and interacting with a teen review group in a large urban library and conducted 18 interviews with 13 young adults. Although these teens came from diverse backgrounds and experiences, she found that they all interacted dynamically with worlds of stories and invited her to do the same, which became an ongoing challenge for her as a researcher to keep up with the books, films, and self-created texts the teens offered. Wolf

The International Journal of Information, Diversity, \& Inclusion, 3(2), 2019

ISSN 2574-3430, jps.library.utoronto.ca/index.php/ijidi/index

DOI: $10.33137 /$ ijidi.v3i2.32589 
observed five ways the teens engaged with young adult literature, which she framed as metaphors: reading as navigation, reading as sleuthing, reading as writing, reading as belonging, and reading as pleasure. These empirical studies confirm two important aspects of library services for adolescents. First, youth seek not only the materials that libraries provide, but also the opportunities for discourse around these texts with both peers and knowledgeable adults. Second, their reading of texts serves multiple aims, including personal and communal; a multiplicity of purpose that reflects the diverse goals of the public library itself.

\section{Adolescents After School}

Starting in the late 1980s, a substantial body of work on voluntary learning emerged from the decade-long Spencer Foundation sponsorship of Milbrey McLaughlin (public policy analyst) and Shirley Brice Heath (linguistic anthropologist) on non-school-related activities of disenfranchised youth in rural, mid-sized, and urban settings. These scholars set out to identify features of access in these communities that might help explain how some youth living in the most difficult of circumstances (and often with rapid growth in gang and drug violence) "made it" into mainstream adulthood. Their findings made clear that critical to these youth were organizations ranging from religious groups to libraries to Boys and Girls Clubs and Little League baseball teams. In these groupings, young people gathered voluntarily, practiced, organized projects, and they learned organizational skills, ways to plan for the future, and strong communication skills (Heath, 1991, 1996; Heath \& Langman, 1994; Heath \& McLaughlin, 1994; McLaughlin, Irby, \& Langman, 1994).

Since the first decade of the joint work noted above, Heath has continued to follow ways that families from a variety of socio-economic classes have adapted in their fundamental interactions. With two-working-parent households on the increase, young people spend less and less time in their own homes and with family members. In observing the family activities of the adults she had studied 30 years earlier (focusing on the children of these families), Heath (2012) found a considerable decrease in the amount of talk in the families created by these children when they reached adulthood. The features of family talk had shifted as well. Contemporary dialogues involve much less back and forth around information, opinion, clarification, and confirmation. Today, parents most frequently request schedule details and personal preferences instead of delving into conversations on topics known to both partners, but having nothing to do with the behavior of either members of the dyad. Such a finding is significant considering the importance of deliberative dialogue skills in many situations, including higher level academics (Hyland, 2009; Morita, 2009; White \& Lowenthal, 2011) and democratic processes (Dryzek, 2000; Mutz, 2006; Gutmann \& Thompson, 2004).

Peer associations and groupings that operate in homes, parking lots, and fast-food restaurants as well as community organizations have taken over much of the socialization for adolescents in much of the United States (Heath, 2012). Yet some of these young people find their way into concerted involvement in organizations that require intensive practice and strong associations with adults who coach, guide, reprimand, and direct the ways in which young people practice skills and think in meta-cognitive ways about what they do voluntarily (Heath \& Langman, 1994). Central in these settings is the refusal to categorize young people, a feature that applies in exemplary programs of libraries as well as sports and arts programs. Adult leaders in these contexts have little desire to peg young people according to their rank in school class or achievement in particular school subjects (Heath, 1996; McLaughlin et al., 1994).

The International Journal of Information, Diversity, \& Inclusion, 3(2), 2019

ISSN 2574-3430, jps.library.utoronto.ca/index.php/ijidi/index

DOI: $10.33137 /$ ijidi.v3i2.32589 
In addition to general studies of youth involved in activities of their own choosing, a considerable amount of research looks at young people involved in particular kinds of structured activities ranging from sports to arts (Heath \& Smyth, 1999). Others consider the role of youth in special programs, such as Youth Radio (Chávez \& Soep, 2005, 2010) or el Sistema youth orchestras in the United States (Heath, 2016). Some examine ways in which young people both work and learn in museums and their special programs (Heath \& Gilbert, 2015). Many of these studies consider the role of voluntary learning that comes as young people have opportunities in such settings to learn to play and to take part in extended conversations with adults who share their interests.

\section{Methods}

To explore the multiple meanings and features of a complex context like the public library, I choose qualitative methods, including observations, semi-structured interviews, and participant action research (Merriam, 2009). My sociocultural-historical theoretical stance guided documentation of "the structure and development of human psychological processes emerg[ing] through culturally mediated, historically developing, practical activity" (Cole, 1996, p. 108). Congruent with this perspective is the need to focus on social interactions as they occurred in combination with participants' narratives of their practices. In addition to observing activities and practices generally, I attended particularly to the use of language in the setting and the achievement of meaning gained through communication among the participants.

The selection of the case for this study was achieved through purposeful sampling (Merriam, 2009, p. 79). I first interviewed librarians who hold administrative positions in three separate library systems for suggestions of teen services librarians with active teen programs. From the list, I identified two sites of interest that met certain criteria (Patton, 2002, p. 243), making a "unique sample" (Merriam, 2009, p. 78). The criteria included having a dedicated teen services librarian for at least 20 hours per week, a steady clientele of adolescents in the library space, regular offerings of programs for young adults, and a core group of teens that function as a teen advisory board. Requiring such criteria for my case study ensured a larger set of activities and interactions for analysis. Additionally, I sought a library with a diverse patron base so I could observe a range of interactional styles in the setting. The combination of these ideal criteria offered both rich data as well as the possibility of exemplary practices in teen services.

\section{Data Collection}

For 18 months, I collected data as a participant observer (Merriam, 2009) in the public library space and at planned events for teen patrons. Observation protocol focused on the conversations between participants and youth movements to and from activities in the space. When attending programs, the teen services librarian introduced me alternately as "a student at the university doing a project" and "another librarian interested in teen services." My identity and research were fully explained each fall to the Teen Library Council, the teen volunteer group for the library. Follow-up interviews involved semi-structured conversations about library activities. Throughout data collection, I wrote conceptual memos about discoveries, created analytic questions to further investigate the data, and built metaphors and concepts (Merriam, 2009, pp. 170-173). My research experiences outside of libraries assisted me in developing a critical eye to balance my insider stance as a former librarian of ten years. To be sure, during the actual term of the research reported here, I made certain during data collection to see with a fresh perspective, trying always to blind myself as much as possible to any prior perceptions about what "should" or even what "could" happen under certain circumstances. Table 2 details the

The International Journal of Information, Diversity, \& Inclusion, 3(2), 2019

ISSN 2574-3430, jps.library.utoronto.ca/index.php/ijidi/index

DOI: $10.33137 /$ ijidi.v3i2.32589 
tools of collection and sources of data.

Table 2. Data Collection

\begin{tabular}{ll}
\hline Tool & Sources \\
\hline Observations & $\begin{array}{l}101 \text { hours over } 68 \text { visits during an 18-month observation } \\
\text { period. Detailed field notes about arrangements of the } \\
\text { space, movements of patrons and staff, and dialogues } \\
\text { between the teen services librarian and youth patrons. }\end{array}$ \\
& $\begin{array}{l}\text { Post-observation follow-up interviews with three members } \\
\text { of the library staff and five adolescent library patrons. } \\
\text { Participants narrated their literacy and library experiences } \\
\text { from early life to present. }\end{array}$ \\
& $\begin{array}{l}\text { Written reflections and } 20 \text { picture book reviews by six teen } \\
\text { volunteers. Volunteers were trained in critical textual } \\
\text { analysis techniques. }\end{array}$ \\
\hline
\end{tabular}

Table 3. Sample Codes

\begin{tabular}{ll}
\hline Stage & Examples \\
\hline Descriptive or Open Coding & $\begin{array}{l}\text { Teen gives critical info; Librarian will read/look; Problem } \\
\text { solving; Negative to positive; Follow-up / return } \\
\text { conversation; Youth recommendation; Socializing; Working } \\
\text { together; Sharing a resource; Giving context (unasked); } \\
\text { Vocabulary; Social issues; Career path; College }\end{array}$ \\
Research Related Coding & $\begin{array}{l}\text { Language Type: relational, referential, or extensional; } \\
\text { Activity: talking, playing, composing, or making }\end{array}$ \\
Refined Categories/Codes & $\begin{array}{l}\text { Questions from Teens: for resource, for information, for } \\
\text { personal, or for clarification; Conversation Content: media } \\
\text { text, school event, home event, community event, library } \\
\text { event, or pre-US arrival event }\end{array}$ \\
\hline
\end{tabular}

\section{Data Analysis}

I used the "constant comparative perspective" (Heath \& Street, 2008, p. 32), searching within my data corpus to find patterns of co-occurrence, a method used in ethnographic qualitative research (Heath \& Street, 2008). Analysis of these patterns happened through an iterative process of writing memos, coding, categorizing codes by theme, and reviewing literature. My coding was grounded in related research and the categories included conversation topics,

The International Journal of Information, Diversity, \& Inclusion, 3(2), 2019

ISSN 2574-3430, jps.library.utoronto.ca/index.php/ijidi/index

DOI: $10.33137 /$ ijidi.v3i2.32589 
references to verifiable resources, types of questions, and direction of speech (i.e. librarian to teen, teen to teen). I also developed a list of descriptive or open codes to capture unforeseen patterns (Merriam, 2009, pp. 178-179). As I continued to analyze data and refine my coding, categories emerged based on the practices I had observed and the narratives that participants shared with me. Both literature-based and descriptive codes were refined into analytic codes and categories (Merriam, 2009, pp. 179-180) through the iterative process of reviewing conceptual memos and research literature. Table 3 contains sample codes at different stages of development.

\section{The Case}

\section{The Community}

The city of Goldash ${ }^{1}$, an intersection of residential, commercial, and industrial spaces, brings longtime residents and newly arrived immigrants into coexistence. Home to 19,107 residents who speak 59 languages and live in 7,157 households, the small city consists of nine neighborhoods with a mix of suburban, urban, and industrial layouts and incomes ranging from lower to uppermiddle ${ }^{2}$. Bordered by a large, increasingly wealthy city, Fairbay, Goldash maintains its status as a home for middle to low-income residents that now includes mostly minority families, pushed out of the housing market in the larger city. Proximity to an international airport, along with increased job opportunities of Fairbay, has made Goldash a preferred landing place for new immigrants to the country. According to U.S. Census figures, Goldash's foreign-born population has evolved from 834 residents in 1990 to almost 8,000, approximately $40 \%$ of its population in 2016. Over the years, immigrants from different regions have come in waves to the area: Bosnians, Serbs, Vietnamese, Laotians, and Cambodians were followed by Somalis, Ethiopians, and Eritreans, and the most recent arrivals have come from Myanmar (Burma), Nepal, Iran, and Iraq. Many of these immigrants are dedicated Muslims, and a range of community and commercial operations have developed to meet their commercial and religious needs. After the 2010 census, the city's zip code was declared one of the most diverse in the nation.

The Goldash School District educates approximately 3000 students in three elementary schools, one middle school, and one high school. A third of Goldash households include children under the age of eighteen, and more than a quarter of Goldash households live below the poverty line. A national newspaper declared this school district the most diverse in the U.S. in 2011, with a diversity index ${ }^{3}$ of $75 \%$. After 2012 , the high school made a remarkable turnaround, raising both test scores and morale through culturally relevant changes to both the curriculum and the discipline policy. What followed was a vastly improved graduation rate as well as a sense of community-belonging amongst adolescents with wildly divergent backgrounds.

Major highways crisscross Goldash, effectively separating the city into four geographic areas, none of which is easily accessible to any other. Therefore, the public library, the middle school, and high school, all located within two blocks of each other and alongside an internationallythemed commercial district, create the city's best opportunities to mix cultures and classes. Car traffic is dominant, and adolescents depend on family and friends for mobility beyond their home and school neighborhoods. During the summer, the city offers educational activities for younger youth while older youth seek employment. Throughout the school year, the middle and high schools offer a limited number of afterschool clubs.

The International Journal of Information, Diversity, \& Inclusion, 3(2), 2019

ISSN 2574-3430, jps.library.utoronto.ca/index.php/ijidi/index

DOI: $10.33137 /$ ijidi.v3i2.32589 


\section{The Library}

The Brewer Library is one of the Eastrose County Libraries (ECL), a system with 49 library branches over 2,165 square miles. The library system includes all of Eastrose County, excluding the metropolitan city of Fairbay, which maintains its own library system as a part of the city's budget. In contrast, ECL, like many similar library systems, is funded directly through county property taxes. This situation provides a stable source of funding, especially in relation to the up-and-down nature of city budgets. Like all public libraries in recent decades, ECL has embraced information technologies, striving to ameliorate the digital divide by providing free access to the internet through desktop computers, laptops, tablets, and, recently, Wi-Fi hotspots that can be checked out and brought into the home. For a city such as Goldash, with residents in the lower half of the economic spectrum, this arrangement generally works to their advantage in terms of materials, staff, and even facilities.

During the research period, nine of the eleven staff members, were white and, like the majority of libraries, most staff were female with English as their primary language. Yet the library collection housed at Brewer includes materials of various formats in several popular local languages, and library signage is often written in one or more secondary languages. Library patrons, including teenagers, codeswitch comfortably between English and native languages everywhere in the library space. The Teen Services Librarian, Elaine, spends 24 hours a week in the library and community serving teens age 13 to 18 and a bit older. Although a full-time employee, because of the "cluster" management model of ECL, she works the rest of her hours at other libraries.

Table 4. Programs for Adolescent Patrons at the Brewer Library

\begin{tabular}{llll}
\hline Program Title & Description & Participants & Frequency \\
\hline $\begin{array}{l}\text { Teen Library } \\
\text { Council }\end{array}$ & $\begin{array}{l}\text { The council advises the } \\
\text { librarian on library } \\
\text { programs and volunteers } \\
\text { to serve in the library and } \\
\text { community }\end{array}$ & $\begin{array}{l}\text { High school age } \\
\text { volunteers }\end{array}$ & $\begin{array}{l}\text { Monthly meeting } \\
\text { during academic year; } \\
\text { additional volunteer } \\
\text { opportunities weekly }\end{array}$ \\
Teen Book Club & $\begin{array}{l}\text { Teens describe to peers a } \\
\text { book they have read } \\
\text { including the plot (with no }\end{array}$ & $\begin{array}{l}\text { Open to middle } \\
\text { and high school } \\
\text { aged youth }\end{array}$ & $\begin{array}{l}\text { Monthly during } \\
\text { academic year }\end{array}$ \\
& $\begin{array}{l}\text { spoilers), why they read } \\
\text { it, and what kind of } \\
\text { reader would enjoy the } \\
\text { book. Each participant } \\
\text { receives a book galley to } \\
\text { take home for every book } \\
\text { reviewed. }\end{array}$ & & \\
Knitting Circle & & \\
& $\begin{array}{l}\text { An experienced adult } \\
\text { volunteer brings supplies } \\
\text { and guides interested }\end{array}$ & $\begin{array}{l}\text { Open to all ages } \\
\text { (though primarily } \\
\text { attended by }\end{array}$ & Weekly during the \\
& $\begin{array}{l}\text { academic year } \\
\text { and }\end{array}$ &
\end{tabular}

The International Journal of Information, Diversity, \& Inclusion, 3(2), 2019

ISSN 2574-3430, jps.library.utoronto.ca/index.php/ijidi/index

DOI: $10.33137 /$ ijidi.v3i2.32589 


\begin{tabular}{|c|c|c|c|}
\hline Program Title & Description & Participants & Frequency \\
\hline & $\begin{array}{l}\text { attendees in working on } \\
\text { knitting projects while } \\
\text { engaging in conversation. }\end{array}$ & $\begin{array}{l}\text { middle and high } \\
\text { school students) }\end{array}$ & \\
\hline $\begin{array}{l}\text { Game On! } \\
\text { And/or Board } \\
\text { Games }\end{array}$ & $\begin{array}{l}\text { Youth are invited to play } \\
\text { cooperatively with peers } \\
\text { on library-supplied gaming } \\
\text { systems and/or with board } \\
\text { games. }\end{array}$ & $\begin{array}{l}\text { Open to late } \\
\text { elementary } \\
\text { through high school } \\
\text { aged youth }\end{array}$ & $\begin{array}{l}\text { Monthly during the } \\
\text { academic year }\end{array}$ \\
\hline Stuff I Love & $\begin{array}{l}\text { Teens describe to peers a } \\
\text { media source (book, } \\
\text { movie, YouTube channel, } \\
\text { app, etc.) including why } \\
\text { they } \\
\text { read/watched/played it } \\
\text { and who else would enjoy } \\
\text { it. Each participant } \\
\text { receives a book galley or } \\
\text { other prize to take home } \\
\text { for every item discussed. }\end{array}$ & $\begin{array}{l}\text { Open to middle } \\
\text { and high school } \\
\text { aged youth }\end{array}$ & $\begin{array}{l}\text { Weekly during the } \\
\text { summer }\end{array}$ \\
\hline $\begin{array}{l}\text { Banned Books } \\
\text { Week }\end{array}$ & $\begin{array}{l}\text { Teens participate in } \\
\text { games and craft projects } \\
\text { directly related to } \\
\text { discussing why books are } \\
\text { challenged in U.S. } \\
\text { libraries. }\end{array}$ & $\begin{array}{l}\text { Open to middle } \\
\text { and high school } \\
\text { aged youth }\end{array}$ & Yearly event \\
\hline $\begin{array}{l}\text { Valentine's } \\
\text { Program }\end{array}$ & $\begin{array}{l}\text { Teens learn about books } \\
\text { that feature relationships } \\
\text { and compose poetry. }\end{array}$ & $\begin{array}{l}\text { Open to middle } \\
\text { and high school } \\
\text { aged youth }\end{array}$ & Yearly event \\
\hline Teen Tech Week & $\begin{array}{l}\text { Teens experiment with } \\
\text { "makey makey" } \\
\text { components to create a } \\
\text { computer controller from } \\
\text { everyday objects. }\end{array}$ & $\begin{array}{l}\text { Open to middle } \\
\text { and high school } \\
\text { aged youth }\end{array}$ & Yearly event \\
\hline $\begin{array}{l}\text { Girl Rising Film } \\
\text { Showing and } \\
\text { Discussion }\end{array}$ & $\begin{array}{l}\text { Participants view a brief } \\
\text { documentary about } \\
\text { obstacles for girls } \\
\text { receiving education } \\
\text { worldwide and engage in } \\
\text { discussion of the film. }\end{array}$ & Open to all ages & One-time \\
\hline $\begin{array}{l}\text { Paper Towns } \\
\text { Party }\end{array}$ & $\begin{array}{l}\text { Teens participate in trivia } \\
\text { and arts and crafts related } \\
\text { to an upcoming film based } \\
\text { on a popular young adult }\end{array}$ & $\begin{array}{l}\text { Open to middle } \\
\text { and high school } \\
\text { aged youth }\end{array}$ & One-time \\
\hline
\end{tabular}

The International Journal of Information, Diversity, \& Inclusion, 3(2), 2019

ISSN 2574-3430, jps.library.utoronto.ca/index.php/ijidi/index

DOI: $10.33137 /$ ijidi.v3i2.32589 


\begin{tabular}{|c|c|c|c|}
\hline Program Title & Description & Participants & Frequency \\
\hline & novel. & & \\
\hline Minecraft Camp & $\begin{array}{l}\text { Teens learn to build } \\
\text { objects within the online } \\
\text { world of Minecraft and, in } \\
\text { a follow up session, learn } \\
\text { to apply mods } \\
\text { (modifications) in the } \\
\text { software. }\end{array}$ & $\begin{array}{l}\text { Open to middle } \\
\text { and high school } \\
\text { aged youth }\end{array}$ & Twice \\
\hline $\begin{array}{l}\text { Teen Coding } \\
\text { Camp }\end{array}$ & $\begin{array}{l}\text { Teens learn basic coding } \\
\text { strategies through Scratch } \\
\text { and create their own } \\
\text { games. }\end{array}$ & $\begin{array}{l}\text { Open to middle } \\
\text { and high school } \\
\text { aged youth }\end{array}$ & One-time \\
\hline Author Visit & $\begin{array}{l}\text { Local author discusses the } \\
\text { writing process with } \\
\text { teens. }\end{array}$ & $\begin{array}{l}\text { Open to middle } \\
\text { and high school } \\
\text { aged youth }\end{array}$ & $\begin{array}{l}\text { One-time (although } \\
\text { other authors were } \\
\text { brought directly to the } \\
\text { middle and/or high } \\
\text { school for } \\
\text { presentations) }\end{array}$ \\
\hline Learn to Draw & $\begin{array}{l}\text { Local artist demonstrates } \\
\text { techniques for creating } \\
\text { characters to put in } \\
\text { comics or graphic novels. }\end{array}$ & $\begin{array}{l}\text { Open to late } \\
\text { elementary } \\
\text { through high school } \\
\text { aged youth }\end{array}$ & One-time \\
\hline
\end{tabular}

Just as public schools tend to have inequalities based on their neighborhood, so do public libraries in terms of "programs," the free activities offered in the library for different age groups. Library programs range widely in topic, including everything from artist performances to console gaming competitions to crafting activities. ECL does not expect the system budget and resources to cover all programming needs. Communities provide resources for themselves through a volunteer fundraising group, resulting in the ironic inequalities similar to schools with more and less affluent Parent Teacher Associations. In communities like Goldash, there are fewer volunteers and fewer funds to raise despite a much greater need for frequent programs, regular snacks, and experiences in a range of subjects, especially for youth. During eighteen months that I spent at the Brewer Library, Elaine's budget for teen programming ranged between zero to $\$ 500$, depending on the year. Yet youth and their families have come to expect and rely on the library's consistent provision of activities, especially in the afterschool hours. Elaine aims to provide programs that meet educational, recreational, and social needs for adolescents, presenting or hosting five to six programs a month. Table 4 inventories the range of programs I observed while in the field.

\section{Findings}

By spending extended time interacting with a consistent set of teen library volunteers, I was able to observe and document changes in youth practices and discourses. The following data, taken from observations and interviews, exemplify how regular participation in library practices and

The International Journal of Information, Diversity, \& Inclusion, 3(2), 2019

ISSN 2574-3430, jps.library.utoronto.ca/index.php/ijidi/index

DOI: $10.33137 /$ ijidi.v3i2.32589 
discourses positively impacted the literacies of three different young women.

\section{Where All Readers Are Equal}

While putting away chairs after a Teen Library Council meeting, I heard squeals of delight burst out behind me. I turned around to see Brigid, Faith, and another girl standing together, bouncing on their toes with excitement while discussing a book series. While the rest of us filed out, I heard the continued exclamations - "Oh my gosh, yes!" "I couldn't believe it when he did that!" "Didn't you just love it?" It was clear that each girl reveled in this moment with an affinity group of book lovers.

As I came to know Brigid and Faith better, I could see how the public library offered them space to be themselves as well as to expand the scope of their identities. In follow-up interviews with each girl, I was struck by their similarities, starting with the fact that each declared themselves to be a "book nerd" within moments of speaking. The following is a discussion of further parallels in their literacies.

Both girls fit a typology I crafted after working with various youth readers which I call "story consumers." They love good stories, grabbing them in any form offered. These girls' early experiences with books often tied into their favorite preschool television programs on the Disney Channel, Nickelodeon, and the Public Broadcasting System (e.g. Disney Fairies, Disney Princesses, Curious George, Charlie \& Lola). Each latched onto reading interests inspired by a parent. Faith found the comic strip Calvin and Hobbes in her father's daily newspaper, leading her to read and eventually gather book collections of the strip. Brigid inherited her father's Serendipity books for young readers and added to the collection through scouring used bookstores. As adolescents, they both watch television series popular with teens, especially ones based on or related to books, such as Vampire Diaries and Riverdale. Each reads a range of fiction, tending toward popular young adult series, but each has one series they hold dear, return to regularly, and seek extensions of through other media including fan-created writings and art. For Brigid, this is the mythology-fueled modern world created by Rick Riordan while Faith savors all things related to J.K. Rowling's wizarding world. The girls use their identification with and knowledge of these story worlds to connect with other people. For example, as I was finishing up field notes at the end of a program observation, I was startled to find Faith by my side, shooting rapid fire questions in my direction: "What's your favorite Harry Potter book?" "How many times have you read them?" "What did you think when Sirius died?" "Do you know what your patrons would look like?" As I answered her questions, I realized that during the previous event I had mentioned loving the Harry Potter series myself, thus inspiring Faith's interest in confirming my fan-identity and connecting with me further.

The girls described parental support for their avid reading, even though both sets of parents push them to read something more than young adult fiction. But they also described close relatives, cousins of Brigid and siblings of Faith, who "don't get the reading thing" and require the girls to extol the virtues of being readers and defend collecting books in their spaces. Each described their bedroom as "covered in books" and Faith's sister drew a line down the middle of their shared room over which she is not allowed to let a book slide. Both expressed a preference for paperbound books, describing the joy of a book's smell and feel, yet both also regularly read ebooks for ease of use while in transit. The girls good-naturedly describe their peers' addiction to mobile phones, though both make use of technology themselves, and lament the friends who do not regularly visit the library. When I asked them to hypothetically talk with one of those friends

The International Journal of Information, Diversity, \& Inclusion, 3(2), 2019

ISSN 2574-3430, jps.library.utoronto.ca/index.php/ijidi/index

DOI: $10.33137 /$ ijidi.v3i2.32589 
about the value of the library, each girl emphasized that the library is more than a space for books, offering examples of activities, and described how the library allows you to connect with personal interests and learn about self-selected topics:

Faith: A library is where you can do, where you can get many kind [sic] of books that interest you. Like, I know you don't like reading books, but something will catch your eye and you can go to many different, many fun activity [sic] there too. Like, what do you like? I'd ask her what she likes, da-da-da. They probably have a good app or have a class or might help you check out books on that or events. Like that.

In her hypothetical advice to a peer, Faith expresses her admiration for the library as a place for books as much as a place for active connections. Brigid also mentioned equal fondness for the library's books and the opportunities to meet other teens.

Despite their many similarities, their differences could easily have kept them isolated from each other. Instead, the democratic practices of a public library brought them together and opened up spaces for joint participation and friendship. Brigid looks like the television stereotype of a teen girl who likes to read. Pale white skin and brown hair usually pulled up in a ponytail, she wears dark-rimmed "librarian" glasses, t-shirts bearing pop culture icons, jeans, and tennis shoes. Faith also prefers tennis shoes, but these do not often stand out under her typical long dark dress. What you likely notice first is her hijab and the medium brown face peering out from it. In another setting, with a less self-aware adult than this community's teen services librarian, Brigid could easily become the favored program participant. She appears to be "one of us," a monolingual white girl with a passion for reading who likes to hang around anyone, especially an adult, who will talk about books. She is the kid many are likely to expect to find hanging out in the teen section of an American public library or bookstore. And yet Faith, a Muslim child of Somali immigrants, is just as passionate for books and as eager to connect with other readers. Her English may be accented, but she gabbles on about books, movies, and television shows like every avid story consumer I have met. Within the Brewer Library, both girls find a place to be themselves, to meet others like them, and to have their interests equally respected, supported, and even expanded by a caring adult.

Brigid and Faith each spoke of the library as a "hideout" from the pressures of home and school, a space to relax and read. Drawn to the library space by their interests, it also levels their social playing field for different reasons. Brigid lives nearby but goes to school in a neighboring town, where her family lived previously. Therefore, she does not go to school with neighborhood teens, but she can build relationships with them in the library. Faith's English vocabulary remains behind her peers with similar family histories, impacting her school experiences. Her placement in classes for English language learners puts barriers between her and classmates more fluent in English. Yet, at this public library, limited language skills do not bar youth from consistent participation with peers. Faith gamely joins dialogues around texts, occasionally pausing to search for vocabulary or rephrase herself to get her message across. In this way, the library provides the girls a venue for building their social skills through shared discourse and experiences.

Both girls attend the library's monthly Teen Book Club as often as they can as well as any other teen program happening while they are present (which is often). They use every opportunity to chat with Elaine, the teen services librarian, about books and often open the conversation to other areas of their lives. Elaine responds with enriched conversation, offering resources and

The International Journal of Information, Diversity, \& Inclusion, 3(2), 2019

ISSN 2574-3430, jps.library.utoronto.ca/index.php/ijidi/index

DOI: $10.33137 /$ ijidi.v3i2.32589 
ideas for both entertainment and education needs. Reading may pull them into the library, but their desire for connection and learning pushes them to action in the space. Each joined the Teen Library Council because they saw other teens participating in the council and followed their curiosity. Unlike many school- and community-based activities, membership on the council requires no audition or special skills beyond being a high-school-age student who can commit to service hours. Not even limited English skills bar anyone from participation. Most teen members speak at least one other language and Elaine and the teens encourage code-switching when someone needs to get their message across.

When Elaine asks for library council volunteers to assist at teen programs, Brigid and Faith raise their hands if it fits their schedule, regardless of the topic of the activity. The result has been to push at each girl's knowledge base, skill set, and even understanding of the world. Faith co-led discussions with teen and adult patrons at two types of programs- a community reading program and, later, a library showing of a documentary film. Although visibly nervous the first time, Faith carefully read the prearranged discussion questions to her audience and listened eagerly to the responses. By the second event, she confidently asked the group questions while contributing her own thoughts as well. Faith reported that her favorite council activity was conducting a youth housing survey because the teen volunteers made it into a competition. She found competing on equal footing with peers to be particularly motivating. Brigid first volunteered in the Book Buddies program, where she guided younger children practicing their read-aloud skills. Later, through her participation in a critical picture book analysis project, Brigid confronted different aspects of her identity. While white female characters abound in children's literature, she realized another element of her experience, her family's practice of pagan traditions, rarely showed up. When it did appear in books, Brigid often found the practices distorted into a form of fantasy or associated with evil. Bringing this issue forth in project discussions enabled the whole team of teens to reflect on additional examples of other religions being misrepresented to further a fictional plot line. Previously awkward with these teens from another school, Brigid now engaged them in personally meaningful conversations.

\section{Pursuing Diversity in Discourse}

Another girl, Zavi piqued my interest during a monthly Teen Book Club session. Previously, Elaine modified the traditional book club model after observing that different kids pop into the program each month.

Elaine: I realized that if you don't have that continuity, having everybody read the same book is kind a recipe for a disaster. We just started doing it as a genre-based book club at the library, and eventually that morphed into just come in and book talk to us. So it's kind of actually pretty simple. I encourage them to give a short plot synopsis and then say what you like about it, review the book and recommend it and why. I give away my advanced reader copies [of new teen books] when they finish book talking.

Because of this adaptation, the monthly Teen Book Club was consistently one of the most popular programs, with young patrons requesting more occurrences. A variety of middle schoolers make up most of the attendees, with older readers like Brigid and Faith popping in as much as their schedules allow. Regardless of the age differences, the teens usually discuss young adult novels, graphic novels, or books assigned in school.

The International Journal of Information, Diversity, \& Inclusion, 3(2), 2019

ISSN 2574-3430, jps.library.utoronto.ca/index.php/ijidi/index

DOI: $10.33137 /$ ijidi.v3i2.32589 
When it was Zavi's turn to speak at book club, she said she was reading Maya Angelou's Why the Caged Bird Sings, but could not understand why she found it in a list of poetry books since it seemed like a memoir. Through Elaine's expert questioning, Zavi explained that she recently discovered an affinity for poetry, especially written from the perspective of people of color. This could have become an awkward social moment for Elaine, Zavi and the group, since the rest of the teens currently had neither knowledge of nor interest in similar books. The usual flow of dialogue between book club participants might have dried up. Instead, Elaine's skills enabled her to respond easily on the topic. She brought up poets who had spoken locally and made a recommendation for Zavi's next read. Zavi appeared sincerely pleased at finding a conversational partner for her interest. Over the next hour, as each teen took a turn talking about a book, two parallel dialogues emerged. Elaine deftly moved between discussing the usual genres with the rest of the teens and discussing diverse poets with Zavi. After the meeting, Zavi remained to further the conversation with Elaine. In turn, Elaine shared that her own desire to better understand the realities of African-Americans recently led her to create a personal book club that reads the work of Black activists. Delighted to hear about Elaine's efforts, Zavi offered a reading recommendation of her own for the group. Elaine made a note of the recommendation while encouraging Zavi to make further suggestions as she thought of them. Throughout the rest of my observations in the field, Elaine continued to follow up on Zavi's reading choices and they exchanged book titles regularly.

Later, as a member of the Teen Library Council, Zavi suggested creating a book display about authors of color and finding other ways to promote their work. She also volunteered for our participatory action research project, analyzing children's picture books that reflected her North African heritage and/or Muslim faith. Because Zavi was already pondering issues of representation in writing, her thoughtful comments and written reflections helped move the group forward in their thinking. When the team wrote to share insights from their work searching for and reading picture books, she wrote:

The books written whose setting was somewhere in the continent of Africa were not written by people from Africa. They were mostly White authors which makes me wonder: would the books that take place in Africa be as highly accredited and successfully published if they were written by Black authors?

In a post-reading reflection document, Zavi articulated a dilemma that many adults in the book industry still wrestle with today:

I learned that literature can be culturally appropriating too...I recognized that I was very critical when I was reading the books and I asked myself a couple times would I rather have a perfectly compiled story with culturally accurate details and have a few of them or would I rather have lots of picture books with lacking a little bit of cultural accuracy? Then I realized in the realm of children's picture books there's an iota of books that take the African narrative and within the iota there are lots of mistakes or the stories written are bland. I think there is lots of room for growth in children's literature and hopefully it gets better.

As Zavi matures, so does her literary life. Her reading has become a tool for exploring and celebrating underrepresented narratives. Through conversations with Elaine at the library, she found someone to help expand her reading life in the direction she desires. Participation in additional library activities brings Zavi greater opportunities to contextualize her reading as well

The International Journal of Information, Diversity, \& Inclusion, 3(2), 2019

ISSN 2574-3430, jps.library.utoronto.ca/index.php/ijidi/index

DOI: $10.33137 /$ ijidi.v3i2.32589 
as opportunities for self-reflection.

\section{Discussion and Conclusions}

Portraits of Brigid, Faith, and Zavi answer the question of how a public library can contribute to the literacy lives of a diverse community of adolescents. The girls' library-based experiences show their practices and style of discourse expanding their personal literacies. The public library's core values of democracy and diversity surrounded the girls and created unique opportunities for transformation. In real time, these values, noted below, overlap throughout library experiences.

\section{A Democratic Space Created by Practices}

In the Brewer Library, patrons of all backgrounds had equal freedom to choose activities and intellectual pursuits. Regular library staff developed relationships with young patrons and maintained a policy, both in speech and action, that teens are equal in status to other patrons and as deserving of attention as a person of any other age. This policy was not upheld perfectly all the time. Near the end of my fieldwork, it became inconsistent due to staffing changes. When another library in the system closed for renovation, staff members were sent to work at other locations. The additional staff who rotated through the Brewer Library were not accustomed to high volumes of teenage patrons. When on duty, these new staff were less patient with adolescent behaviors, resulting in a less comfortable environment for the teens. Some librarians have noted that on occasion libraries welcome teenagers in as policy but not in practice. This lack of welcome at times extends to an unpleasant reality in which libraries do not provide solid levels of funding and staffing for teen services, because neither staff nor adult patrons want to deal with teenagers in the library space.

But teens I observed and spoke with during my research valued the Brewer Library space for the democratic freedoms offered there, including the pursuit of intellectual interests not supported elsewhere. They relished the chance to participate in enriched group activities. The only entry requirement for participation in almost any library program is a willingness to show up. Even membership in the Teen Library Council is open to anyone of high school age committed to volunteering. In the library, there is no segregation of young people by grade and never by their ability. The teen services librarian does not give teens a test to see how well they will participate in the conversations. In fact, in this particular library, many English Language Learners regularly attended these activities, and every effort was made to encourage full participation, including codeswitching between English and home languages. Such flexibility encourages involvement in ways that meet the individual needs of each youth.

Such practices created a democratic space in which Brigid and Faith could enjoy each other on an equal playing field. Finding these two self-proclaimed book nerds hanging out in a public library may not be surprising, but how did they benefit? Aspects of each girl's identities could have isolated them from peers. Brigid attended school outside the neighborhood and practiced a little understood pagan religion while Faith's English abilities were behind most of her Muslim and second-generation immigrant peers. In the Brewer Library, these girls became connected to each other, the librarian, and other book lovers, as well as to a diverse set of individuals and ideas through interactive library programs. These experiences widened the context of each girl's individual reading pursuits. Here in the library's democratic space, the girls could follow their curiosity and expand their personal literacies into community-based connections.

The International Journal of Information, Diversity, \& Inclusion, 3(2), 2019

ISSN 2574-3430, jps.library.utoronto.ca/index.php/ijidi/index

DOI: $10.33137 /$ ijidi.v3i2.32589 


\section{Diversity in Discourse Facilitated by a Librarian}

The youth who use the Brewer Library encounter a wide range of people, materials, and activities circulating within the space. But access to such resources is often not sufficient for impacting the young. A key component to literacy development within the public library is how the adults who work there forge relationships between people and across ideas through conversation. Talking regularly with youth, teen services librarians such as Elaine contextualize experiences coming from the worlds of adolescents (Vygotsky, 1978). For example, Zavi had moved beyond the reading interests of her peers as well as the curriculum of her current English class. Isolation could have easily followed, but in the public library she could attend activities with her teenage friends, engaging in relevant, meaningful dialogues with them and with the librarian. Here in the public library she not only found resources, but also deepened understanding of these through ongoing discourse with Elaine.

Linguists who study the conversational patterns of teenagers note that with the coming of technologies of rapid and brief communication, in-depth conversations for many teenagers are disappearing or slowing (Heath, 2012). Families that include a child with special needs, an ailing elder, or one or both parents who work two jobs and travel long distances for their work have little time for sustained conversations with their teens. Direction-giving, instrumental questions, and simple requests constitute much of the talk within such homes. Even in middle-income families, conversational time has fallen away with the volume and variety of individual entertainment options in other spaces of the household beyond the kitchen or family room. For the modern teenager, Elaine's discourse skills matter more than ever. Teens have curiosity about topics, special interests or needs, and often yearn for after-school company of peers and supportive adults. At the library of this study, Elaine's conversational openers, along with her genuine interest in what teens think, want, and do, opened the teens to back-and-forth talking and topic continuation. Such times often led Elaine to walk casually to a bookshelf and pull out just the right book or DVD or magazine. Thus the conversation continued in another mode. The dialogue would extend even further when Elaine next met the youth and asked follow up questions to elicit their thoughts. These conversational openers were neither test nor trick questions, as may be the case with some situations. Individual young people and their ideas are of genuine interest to her. Through ongoing discourses filled with diverse ideas, Elaine contributes to the literacy development of the teens she serves.

Elaine's professional experiences and continuing education trained her to provide such contextualized connections for youth that fit their needs. She uses diversity in her discourse, flexibly individualizing services with open-ended questions and follow-up conversations to create trusting relationships. But Elaine is only allowed 24 hours per week to work in or for the Brewer Library, resulting in fewer opportunities for this kind of interaction. While many librarians use a similar discourse, not all are as skilled as Elaine, especially when faced with teenagers. On occasions when another staff member or volunteer led a teen program in Elaine's place, the discourse was noticeably different. Substitute adults used more closed-ended questions and were less familiar with the young people. Conversations were either non-existent or much shorter than those with Elaine.

\section{Limitations and Future Directions}

As with most qualitative research, the findings of this single empirical case study cannot be generalized to all of the nearly 17,000 U.S. public libraries. Variations in space, resources, staff,

The International Journal of Information, Diversity, \& Inclusion, 3(2), 2019

ISSN 2574-3430, jps.library.utoronto.ca/index.php/ijidi/index

DOI: $10.33137 /$ ijidi.v3i2.32589 
and patronage make each library unique. To grasp the public library's full contribution to adolescent literacy, quantitative and qualitative measures must be applied in diverse settings. For example, the ALA and the IMLS regularly gather statistics from public libraries, but less frequently do their surveys ask questions relevant to teen services, creating a data vacuum.

However, if more case studies of adolescent readers in their local libraries were carried out with attention to discourse, questioning techniques, and continuation of conversations around known teenager interests, solid comparative analysis would be possible. For example, do public libraries in less diverse communities, with more diverse staff members, or with smaller active teen populations follow the patterns identified here? Or do large public libraries with many spaces for small groups find several librarians who genuinely pursue conversations with teenagers? And do libraries serving middle-class families find young people less interested in talking with librarians than is the case in libraries located in diverse communities? Broadening empirical studies of adolescents and librarians across communities and libraries with different emphases and local cultural offerings would build resources for librarians as well as for teachers and civic leaders.

Despite the limitations of this study, many public libraries should recognize elements of their own stories in the Brewer Library experience. Demographic changes are ubiquitous, changing relationships with local schools shift constantly, and teenage interests alter with the latest singing group or new app. Yet beyond these changes, every public library can act on a professional commitment to democracy and diversity. Portraits of these three readers demonstrate that practices and discourse grounded in these two core values contribute positively to adolescent literacy. In light of these findings, teen services librarians and public library administrators can examine current patterns and make changes to improve access to democratic space and attend to the need for conversational patterns that appeal to adolescents. These understandings can lead librarians to consider barriers, physical and metaphorical, for teen patrons in accessing different resources throughout the day. They can talk with staff about reasonable expectations for adolescent behavior and ways to respond appropriately. In addition, evaluation of the number of librarian hours dedicated to teen services and the levels of training and experience reflected by teen librarians may well be worth considering.

A library often operates as a center of community life-particularly for teenagers. Replacement of the Brewer Library by a commercial organization would mean that Brigid and Faith might cross paths, but would they be connected to each other and their peers through equal opportunities for ongoing adult-teen conversations? Not likely, and neither would be Zavi's chances of receiving much more than a few reading recommendations. Deep follow-up and follow-through conversations around books, teen topics, and library activities matter to teenagers, preparing them for civic life and for thinking ahead to their ongoing lives with their younger siblings, peers, and eventually their own children.

\section{Acknowledgements}

The author gratefully acknowledges the library staff and community members who made this research possible.

The International Journal of Information, Diversity, \& Inclusion, 3(2), 2019

ISSN 2574-3430, jps.library.utoronto.ca/index.php/ijidi/index

DOI: $10.33137 /$ ijidi.v3i2.32589 


\section{Endnotes}

1 All names of places and persons in this work have been replaced with pseudonyms.

2 Statistics in this section come from reports about the community and library system gathered by library administration.

3 This number represents the percent of likelihood that two students selected at random would be members of a different ethnic group.

\section{References}

Agosto, D. E. (2016). What's next in U.S. public library services for teens? A peek into a promising future. Public Library Quarterly, 35(4), 344-350.

Alvermann, D. E., Young, J. P., Green, C., \& Wisenbaker, J. M. (1999). Adolescents' perceptions and negotiations of literacy practices in after-school Read and Talk Clubs. American Educational Research Journal, 36(2), 221-264.

American Library Association (ALA). (1996). Library bill of rights. Retrieved from http://www.ala.org/advocacy/intfreedom/librarybill

American Library Association (ALA). (2004). Core values of librarianship. Retrieved from http://www.ala.org/advocacy/intfreedom/statementspols/corevalues

American Library Association (ALA), \& Association of American Publishers. (2004). The freedom to read statement. Retrieved from http://www.ala.org/advocacy/intfreedom/statementspols/freedomreadstatement

Barniskis, S. C. (2016a). Access and express: Professional perspectives on public library makerspaces and intellectual freedom. Public Library Quarterly, 35(2), 103-125.

Barniskis, S. C. (2016b). Deconstructing the mission: A critical content analysis of public library mission statements. The Library Quarterly, 86(2), 135-152.

Barniskis, S. C. (2017). To what ends, by which means? Information Research, 22(1), 1.

Burek Pierce, J. (2016). The reign of children: The role of games and toys in american public libraries, 1876-1925. Information \& Culture, 51(3), 373-398.

Chávez, V., \& Soep, E. (2005). Youth radio and the pedagogy of collegiality. Harvard Educational Review, 75(4), 409-434.

Chávez, V., \& Soep, E. (2010). Drop that knowledge: Youth radio stories. Berkeley, CA: University of California Press.

Cole, M. (1996). Cultural psychology: A once and future discipline. Cambridge, MA: Harvard University Press.

The International Journal of Information, Diversity, \& Inclusion, 3(2), 2019

ISSN 2574-3430, jps.library.utoronto.ca/index.php/ijidi/index

DOI: $10.33137 /$ ijidi.v3i2.32589 
Critcher Lyons, R. (2016). A rationale for public library civics instruction. Public Library Quarterly, 35(3), 254-257.

Dryzek, J. S. (2000). Deliberative democracy and beyond: Liberals, critics, contestations. New York, NY: Oxford University Press.

Edwards, M. (1974). The fair garden and the swarm of beasts: The library and the young adult, revised and expanded. New York, NY: Hawthorn Books.

Gutmann, A., \& Thompson, D. F. (2004). Why deliberative democracy? Princeton, NJ: Princeton University Press.

Hearne, B., \& Jenkins, C. (1999). Sacred texts: What our foremothers left us in the way of psalms, proverbs, precepts, and practices. Horn Book Magazine, 75(5), 536-558.

Heath, S. B. (1991). "It's about winning!": The language of knowledge in baseball. In L. B. Resnick, J. M. Levine, \& S. D. Teasley (Eds.), Perspectives on socially shared cognition (pp. 101-124). Washington, DC: American Psychological Association.

Heath, S. B. (1996). Work, class, and categories: Dilemmas of identity. In L. Z. Bloom, D. A. Daiker, \& E. M. White (Eds.), Composition in the twenty-first century: Crisis and change (pp. 226-242). Carbondale, IL: Southern Illinois University Press.

Heath, S. B. (2012). Words at work and play: Three decades in family and community life. Cambridge, UK: Cambridge University Press.

Heath, S. B. (2016). The benefits of ensemble music experience (and why these benefits matter so much in underserved communities). In C. Witkowski (Ed.), El Sistema: Music for social change (pp. 73-94). London, UK: Omnibus Press.

Heath, S. B., \& Gilbert, L. (2015). Creativity and the work of art and science: A cognitive neuroscience perspective. In M. Fleming, L. Bresler, \& J. O'Toole (Eds.), The Routledge international handbook of the arts and education (pp. 398-409). London, UK: Routledge.

Heath, S. B., \& Langman, J. (1994). Shared thinking and the register of coaching. In D. Biber \& E. Finegan (Eds.), Sociolinguistic perspectives on register (pp. 82-105). Oxford, UK: Oxford University Press.

Heath, S. B., \& McLaughlin, M. W. (1994). Learning for anything everyday. Journal of Curriculum Studies, 26(5), 471-489.

Heath, S. B., \& Smyth, L. (1999). ArtShow: Youth and community development. A resource guide to accompany documentary ArtShow. Washington, DC: Partners for Livable Communities.

Heath, S. B., \& Street, B. V. (2008). On ethnography: Approaches to language and literacy research. New York, NY: Teachers College Press.

Hyland, K. (2009). Academic discourse: English in a global context. New York, NY: Continuum.

The International Journal of Information, Diversity, \& Inclusion, 3(2), 2019

ISSN 2574-3430, jps.library.utoronto.ca/index.php/ijidi/index

DOI: $10.33137 /$ ijidi.v3i2.32589 
Institute of Museum and Library Services (IMLS). (2015). Fiscal year 2015 data element definitions. Washington, DC. Retrieved from https://www.imls.gov/sites/default/files/pls_defs_fy2015.pdf

Lyons, K. (2018, July 23). 'Twaddle': Librarians respond to suggestion Amazon should replace libraries; Piece in Forbes magazine said libraries 'don't have the same value they used to' and cost taxpayers too much. The Guardian. Retrieved from https: / / www.theguardian.com/books/2018/jul/23/twaddle-librarians-respond-tosuggestion-amazon-should-replace-libraries

McLaughlin, M. W., Irby, M. A., and Langman, J.(1994). Urban sanctuaries: Neighborhood organizations in the lives and futures of inner-city youth. San Francisco, CA: JosseyBass Publishers.

Merriam, S. B. (2009). Qualitative research: A guide to design and implementation. San Francisco, CA: Jossey-Bass.

Morita, N. (2009). Language, culture, gender, and academic socialization. Language \& Education: An International Journal, 23(5), 443-460.

Mutz, D. C. (2006). Hearing the other side: Deliberative versus participatory democracy. New York, NY: Cambridge University Press.

Oltmann, S. M. (2016). "For all the people": Public library directors interpret intellectual freedom. The Library Quarterly, 86(3), 290-312.

Patton, M. Q. (2002). Qualitative research and evaluation methods. Thousand Oaks, CA: Sage.

Randall, R. (2013). All wired up: Understanding the reading and information-searching behavior of teenagers. Young Adult Library Services, 11(4), 19-22.

Shera, J. H. (1949). Foundations of the public library: The origins of the public library movement in New England, 1629-1855. Chicago, IL: University of Chicago Press.

Takahashi, D. (2015, September 27). Going beyond the books and programs: Building real relationships with teens [web log comment]. Retrieved from http://yalsa.ala.org/blog/2015/09/27/going-beyond-the-books-and-programs-buildingreal-relationships-with-teens/

Vygotsky, L. (1978). Interaction between learning and development. In M. Cole, V. JohnSteiner, S. Scribner, \& E. Souberman (Eds.), Mind in society: Development of higher psychological processes (pp. 79-91). Cambridge, MA: Harvard University Press.

White, J. W., \& Lowenthal, P. R. (2011). Minority college students and tacit "codes of power": Developing academic discourses and identities. The Review of Higher Education, 34(2), 283-318.

Wiegand, W. (2015). Part of our lives: A people's history of the American public library. Oxford, UK: Oxford University Press.

The International Journal of Information, Diversity, \& Inclusion, 3(2), 2019

ISSN 2574-3430, jps.library.utoronto.ca/index.php/ijidi/index

DOI: $10.33137 /$ ijidi.v3i2.32589 
Wolf, J. L. (2006). "I just hope there's a sequel." What we can learn from young adult novels and the teens who read them (Doctoral dissertation). Retrieved from ProQuest Dissertations \& Theses. (3209030)

Wolf, S. A., Coats, K., Enciso, P., \& Jenkins, C. (2011). Handbook of research on children's and young adult literature. New York, NY: Routledge.

Sarah A. Evans (sevans14@twu.edu) is an assistant professor with the School of Library \& Information Studies at Texas Woman's University. Her research examines the literacies and identities taken up in voluntary learning experiences in libraries. Dr. Evans holds a bachelor's degree in Drama, a master's in Library and Information Science, and a doctorate of philosophy in Learning Sciences from the University of Washington, as well as an elementary education certificate from Western Washington University. 